\title{
DESIGN OF EARLY FLOOD DETECTION (EFDe) SYSTEM BASED ON IoT FOR FLOOD VOCATIONAL AREAS
}

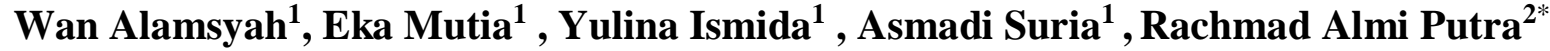 \\ ${ }^{1}$ Department of Civil Engineering, Engineering Faculty, Universitas Samudra \\ Jl. Meurandeh, Langsa Lama - Langsa 24354 \\ ${ }^{2}$ Department of Physics, Engineering Faculty, Universitas Samudra \\ Jl. Meurandeh, Langsa Lama - Langsa 24354 \\ Received: $31^{\text {th }}$ August 2019; Revised: $13^{\text {rd }}$ September 2019; Accepted: $6^{\text {th }}$ October 2019
}

\begin{abstract}
There is an early flood detection tool that has been successfully designed called the Early Flood Detection (EFDe) a system that uses the Internet of Things system which can be accessed by the users through a browser or an Android smartphone. In general, this tool has an accurate sensor response to the water level reading by the sensor. The time needed for the sensor to send data to the server is 10-15 seconds. The speed of this delivery time is influenced by several factors, including sensor response, server response, and the cellular network used. The EFDe system is equipped with an alarm around the location and has 10-15 second response when the indicator shows FLOOD POTENTIAL and will not stop until the signal changed to SAFE. This EFDe System is equipped with a solar panel and solar control charger and has an independent energy source that comes from the sun and stored in batteries. That is why the EFDe system is able to send information in real-time.
\end{abstract}

Keywords: EFDe; System; Nodemcu; Calibration; Indicator

\section{Introduction}

The natural disasters that happen more often in the tropics are hurricanes, landslides and floods. Indonesia is at the equatorial latitude which causes Indonesia to have two seasons, dry and rainy seasons. Indonesia has heavy rainfall, so in the rainy season, almost the whole area is washed down by rain with high intensity. The rainy season usually lasts up to 6-7 months. The buildings, houses, highways, are made by concrete that makes the absorption of rainwater to the ground reduced and the behaviour of disposing of garbage in the water and rivers will become a factor for flooding to happened. ${ }^{1}$

Flood disasters can occur at any time and anywhere. This gives a detrimental impact on the community, especially for residents on the riverside. ${ }^{2}$ Now, flood disaster management is still ineffective in minimizing died victims and other material losses. ${ }^{3}$ The effectiveness of these disaster relief efforts depends on accurate time and information about the

\footnotetext{
*Corresponding author.

E-Mail: rachmad.almi@unsam.ac.id
}

geographical location and the impact of ongoing flood. ${ }^{4}$

IT technology that is developing more rapidly makes researchers increase innovation in designing technology that can help to detect symptoms of the early flood. The use of various sensors and technologies has been widely developed to detect or monitor environmental conditions and flood disasters, including using Doppler radar but it requires a large cost and complicated electronic devices and limited access.

Some related research on flood detection systems that can inform users by a short message sends GateWay. The message tells the water level around the detector. ${ }^{5}$ However, the system has weaknesses, one of them is messages sent only to the user's mobile number that has been registered. Other similar research on the design of GSM-based Flood detection and Information System uses the HCSR-04 ultrasonic sensor. The tool send the location and water level information to the 
user via mobile numbers that have been registered to the system by short message (SMS). ${ }^{6}$

From some of the studies, there is a gap to do a new study on the Design of Early Flood Detection Systems (EFDe) for flood-prone areas. The novelty of this research lies in the use of a microcontroller, that's nodemcu, HCSR05 sensor and also with the Internet of Things (IoT) system which is freely accessible in real-time (Open Source)

\section{Methods}

The method used in this study is divided into three stages, as follows:

- The design stage

This design stage begins by describing the flowchart system to be built (figure 1), and at this stage, the system identification is needed are sensors, indicators, and microcontrollers that are connected to the server through internet network with Wi-Fi modules. Based on this design, it is implemented on the hardware devices.

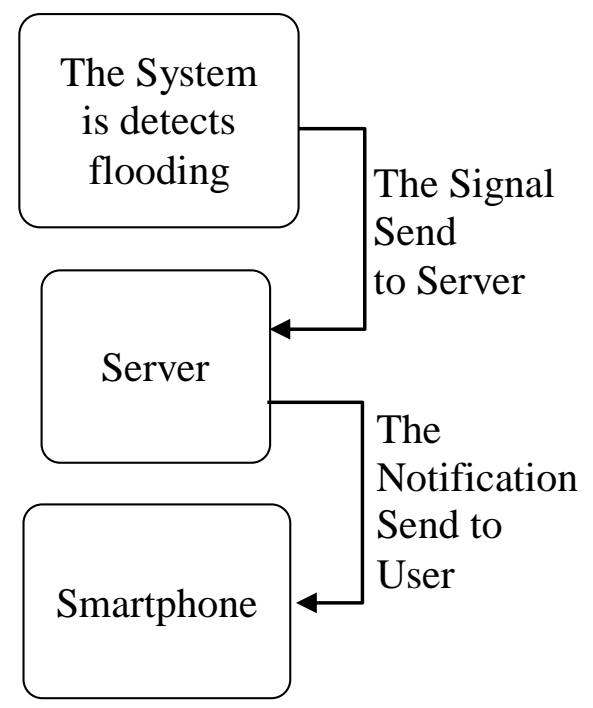

Figure 1. Flowchart General Design Stage

This system consists of hardware and software. The hardware consists of NodeMcu, WiFiESP8266, and several sensors. The sensor used in this equipment is the HCSR04 sensor. Ultrasonic is a sensor that works by sending certain waves and then calculating the time when it is received back by the sensor.

The hardware design schematic is shown in Figure 2.

Software is needed to program a microcontroller that can read and send data to a server with the Internet of Things (IoT) approach to the user.
- Programming Stage

The program language used is $\mathrm{C}$ language through Arduino IDE software which is then uploaded on the microcontroller board. And also HTML as website pages.

- Testing and Calibration Stage

Tests carried out on the hardware to ensure that the sensors on the device can function as expected. After the hardware is tested, a calibration step is performed to determine the error value of the tool 


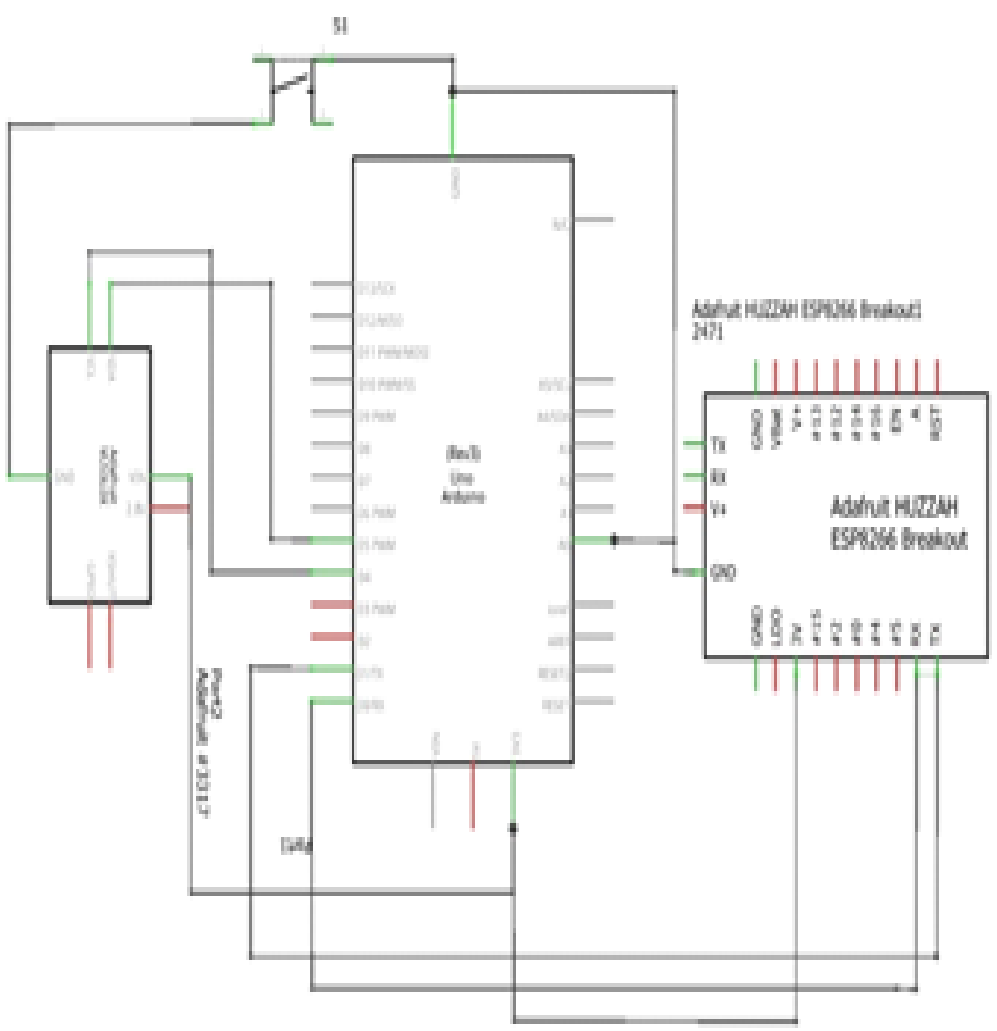

Figure 2. Hardware Schematic

\section{Result and Discussion}

- Connection Testing

The EFDe system testing is carried out by conducting a connection test which includes sending the data to the server. Data in the form of analogue signals provided by sensors are sent to the server via nodemcu. The time that is required to send data is 10 to 15 seconds. The speed of sending data is affected by the sending time (sending information time) and also the response from the server. Besides these two factors, the speed of the data transmission network is also influenced by the cellular network signal. Data sent on the server is displayed in a web page that can be accessed via desktop or smartphone as shown in Figure 3 and Figure 4.

From Figure 3 and Figure 4, there are two main components, the location of the flood station which is the location of the placement of the EFDe system and the indicator table that real-time displays the reading of the water level. The components that are presented in the table are

- The number which is the sensor reading sequence number and this number also represent the delivery that EFDe has made to the server.

- This time column describes the local time data which is received on the server, in the time column displays the year, month, date, hour, minute, and second.

- The description column is an indicator column that explains the safe condition or potential flood based on water level data read by the sensor. 


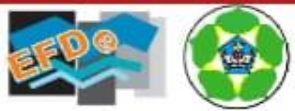

\section{Early Flood Detection(EFDe)System}

Lokasi Station Banjir

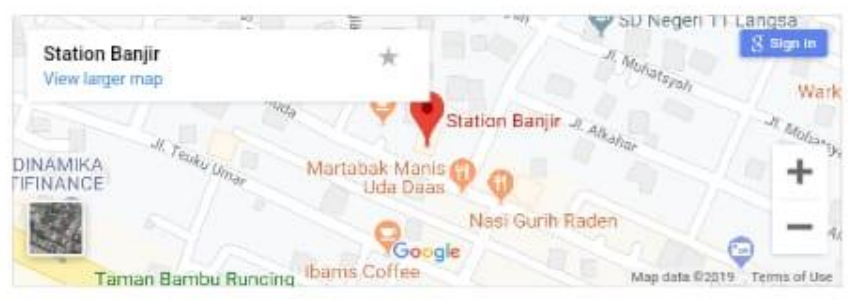

Tabel Ketinggian Air

\begin{tabular}{|l|c|c|c|}
\hline Nomor & Waktu & Tinggi Air $(\mathrm{cm})$ & Keterangan \\
\hline
\end{tabular}

\begin{tabular}{|c|c|c|c|}
\hline Nomor & Waktu & Tinggi Air $(\mathrm{cm})$ & Keterangan \\
\hline 1 & $2019-08-10$ 04:58:28 & 39.64 & AMAN \\
\hline 2 & $2019-08-1004: 58: 28$ & 58.78 & POTENSI BANJIR \\
\hline 64 & $2019-08-1203: 15: 26$ & 80.00 & POTENSI BANJIR \\
\hline 65 & $2019-08-1203: 15: 42$ & 28.79 & AMAN \\
\hline
\end{tabular}

\begin{tabular}{c|c|c|c}
65 & $2019-08-1203: 15: 42$ & 28.79 & AMAN \\
\hline 66 & $2019-08-12$ 03:16:11 & 40.55 & POTENSI BANJIR \\
67 & $2019-08-12$ 03:16:27 & 29.88 & AMAN
\end{tabular}

\begin{tabular}{l|l|l|l}
67 & $2019-08-1203: 16: 27$ & 29.88 & AMAN \\
\hline 68 & $2019-08-1203: 16: 42$ & 30.45 & AMAN
\end{tabular}

\begin{tabular}{l|l|l|l}
68 & $2019-08-1203: 16: 42$ & 30.45 & AMAN \\
\hline 69 & $2019-08-1203: 16: 58$ & 30.12 & AMAN
\end{tabular}

\begin{tabular}{l|l|l|l}
69 & $2019-08-1203: 16: 58$ & 30.12 & AMAN \\
\hline
\end{tabular}

\begin{tabular}{|l|l|l|l|}
\hline 70 & $2019-08-1203: 17: 13$ & 30.07 & AMAN \\
\hline 71 & $2019-08-1203: 17: 29$ & 30.12 & AMAN \\
\hline
\end{tabular}

\begin{tabular}{l|l|l|l}
71 & $2019-08-1203: 17.29$ & 30.12 & AMAN \\
\hline 72 & $2019-08-1203: 17: 44$ & 30.29 & AMAN
\end{tabular}

\begin{tabular}{|c|c|c|c|}
\hline 72 & $2019-08-1203: 17: 44$ & 30.29 & AMAN \\
\hline 73 & $2019-08-1203: 17: 59$ & 80.00 & POTENSI BANJIR \\
\hline 74 & $2019-08-12$ 03:18:16 & 80.00 & POTENSI BANJIR \\
\hline 75 & $2019-08-1203: 18: 45$ & 80.00 & POTENSI BANJIR \\
\hline
\end{tabular}

\begin{tabular}{c|c|c|c}
75 & $2019-08-12$ 03:18:45 & 80.00 & POTENSI BAN \\
\hline 76 & $2019-08-12$ 03:18:56 & 29.14 & AMAN \\
\hline
\end{tabular}

\begin{tabular}{|l|l|l|l}
\hline 77 & $2019-08-1203: 19: 11$ & 29.62 & AMAN \\
\hline
\end{tabular}

\begin{tabular}{l|l|l|l}
\hline 78 & $2019-08-1203: 19: 11$ & 29.62 & AMAN \\
\hline
\end{tabular}

\begin{tabular}{l|l|l|l}
\hline 78 & $2019-08-1203: 19: 27$ & 30.05 & AMAN \\
\hline 79 & $2019-08-1302: 01: 05$ & 22.74 & AMAN \\
\hline
\end{tabular}

\begin{tabular}{c|c|c|c}
79 & $2019-08-1302: 01: 05$ & 22.74 & AMAN \\
\hline 80 & $2019-08-1302: 01: 20$ & 28.64 & AMAN \\
\hline 81 & $2019-08-1302: 01: 36$ & 29.17 & AMAN
\end{tabular}

\begin{tabular}{l|l|l|l}
81 & $2019-08-1302: 01: 36$ & 29.17 & AMAN \\
\hline 82 & $2019-08-1302: 01: 51$ & 29.45 & AMAN
\end{tabular}

\begin{tabular}{l|l|l|l}
82 & $2019-08-1302: 01: 51$ & 29.45 & AMAN \\
\hline 83 & $2019-08-1302-02: 07$ & 29.74 & AMAN
\end{tabular}

\begin{tabular}{c|c|c|c}
83 & $2019-08-1302-02: 07$ & 29.74 & AMAN \\
\hline 84 & $2019-08-1302: 02: 22$ & 29.98 & AMAN
\end{tabular}

\begin{tabular}{l|l|l|l}
84 & $2019-08-1302: 02: 22$ & 29.98 & AMAN \\
\hline 85 & $2019-08-1302: 02: 38$ & 33.21 & AMAN
\end{tabular}

\begin{tabular}{l|l|l|l}
85 & $2019-08-1302-02: 38$ & 33.21 & AMAN \\
\hline 86 & $2019-08-1302-02: 53$ & 24.67 & AMAN
\end{tabular}

\begin{tabular}{c|c|c|c}
86 & $2019-08-1302-02: 53$ & 24.67 & AMAN \\
\hline 87 & $2019-08-1302-03-09$ & 30.12 & AMAN
\end{tabular}

\begin{tabular}{l|l|l|l}
87 & $2019-08-1302: 03: 09$ & 30.12 & AMAN \\
\hline 88 & $2019-08-1302-03: 24$ & 30.14 & AMAN \\
\hline
\end{tabular}

\begin{tabular}{c|c|c|c}
88 & $2019-08-1302-03: 24$ & 30.14 & AMAN \\
\hline 89 & $2019-08-1302-06: 54$ & 80.00 & POTENSI BANJIR \\
\hline
\end{tabular}

\begin{tabular}{l|l|l|l}
\hline 90 & $2019-08-1302: 07: 34$ & 80.00 & POTENSI BANJIR \\
\hline 9 & $2019-08-1306: 14: 59$ & 80.00 & POTENSI BANJIR \\
\hline
\end{tabular}

\begin{tabular}{l|l|l|l}
91 & $2019-08-1306: 14: 59$ & 27.98 & AMAN \\
\hline 92 & $2019-08-1306: 15: 14$ & 28.78 & AMAN \\
\hline
\end{tabular}

\begin{tabular}{l|l|l|l}
92 & $2019-08-1306: 15: 14$ & 28.78 & AMAN \\
\hline 93 & $2019-08-1306: 15: 30$ & 28.98 & AMAN
\end{tabular}

\begin{tabular}{c|c|c|c}
93 & $2019-08-1306: 15: 30$ & 28.98 & AMAN \\
\hline 94 & $2019-08-1306: 15: 45$ & 29.33 & AMAN
\end{tabular}

\begin{tabular}{l|l|l|l}
94 & $2019-08-1306: 15: 45$ & 29.33 & AMAN \\
\hline 95 & $2019-08-1306: 16: 01$ & 29.52 & AMAN
\end{tabular}

\begin{tabular}{l|l|l|l}
95 & $2019-08-1306: 16: 01$ & 29.52 & AMAN \\
\hline 96 & $2019-08-1504: 27: 59$ & 80.00 & POTENSI BANJIR \\
\hline 97 & $2019-08-1504.28: 21$ & 80.00 & POTENSI BANJIR \\
\hline 98 & $2019-08-1504.28: 42$ & 80.00 & POTENSI BANJIR \\
\hline
\end{tabular}

\begin{tabular}{l|l|l|l}
\hline 98 & $2019-08-1504: 28: 42$ & 80.00 & POTENSI BANJIR
\end{tabular}

\begin{tabular}{c|c|c|c}
99 & $2019-08-1504: 29: 04$ & 80.00 & POTENSI BANJIR \\
\hline 100 & $2019-08-1504: 29: 25$ & 80.00 & POTENSI BANJIR \\
\hline
\end{tabular}

\begin{tabular}{|l|l|l|c}
\hline 100 & $2019-08-1504: 29: 25$ & 80.00 & POTENSI BAN \\
\hline 101 & $2019-08-1504: 31: 41$ & 24.17 & AMAN \\
\hline 102 & $2019-08-1504: 31: 56$ & 24.78 & AMAN \\
\hline
\end{tabular}

\begin{tabular}{|l|l|l|}
\hline 102 & $2019-08-1504: 31: 56$ & 24.78 \\
\hline 103 & $2019-08-1504: 35: 15$ & 23.71 \\
\hline
\end{tabular}

\begin{tabular}{l|l}
23.71 & AMAN \\
\hline 24.31 & AMAN
\end{tabular}

\begin{tabular}{|l|l|l}
\hline 105 & $2019-08-1504: 42: 03$ & -22.26 \\
\hline
\end{tabular}

\begin{tabular}{|l|l|l|l|}
\hline 105 & $2019-08-1504: 42: 03$ & -22.26 & AMAN \\
\hline 106 & $2019-08-1504: 42: 18$ & -27.84 & AMAN \\
\hline 107 & $2019-08-1504: 42: 36$ & -17.40 & AMAN \\
\hline 108 & $2019-08-1504: 42: 52$ & -10.93 & AMAN \\
\hline 109 & $2019-08-1504: 43: 07$ & -21.55 & AMAN \\
\hline 110 & $2019-08-1504: 43: 23$ & -26.19 & AMAN \\
\hline 111 & $2019-08-1504: 43: 38$ & -11.47 & AMAN \\
\hline 112 & $2019-08-1504: 43: 54$ & -18.79 & AMAN \\
\hline 113 & $2019-08-1504: 44: 09$ & -6.62 & AMAN \\
\hline 114 & $2019-08-1504: 44: 25$ & -19.98 & AMAN \\
\hline 115 & $2019-08-1504: 44: 41$ & -19.00 & AMAN
\end{tabular}

Copyright(c) 2019. || Universitas Samudra || Penelitian Dosen Muda

Figure 3. EFDe Page Interface for Smartphone 


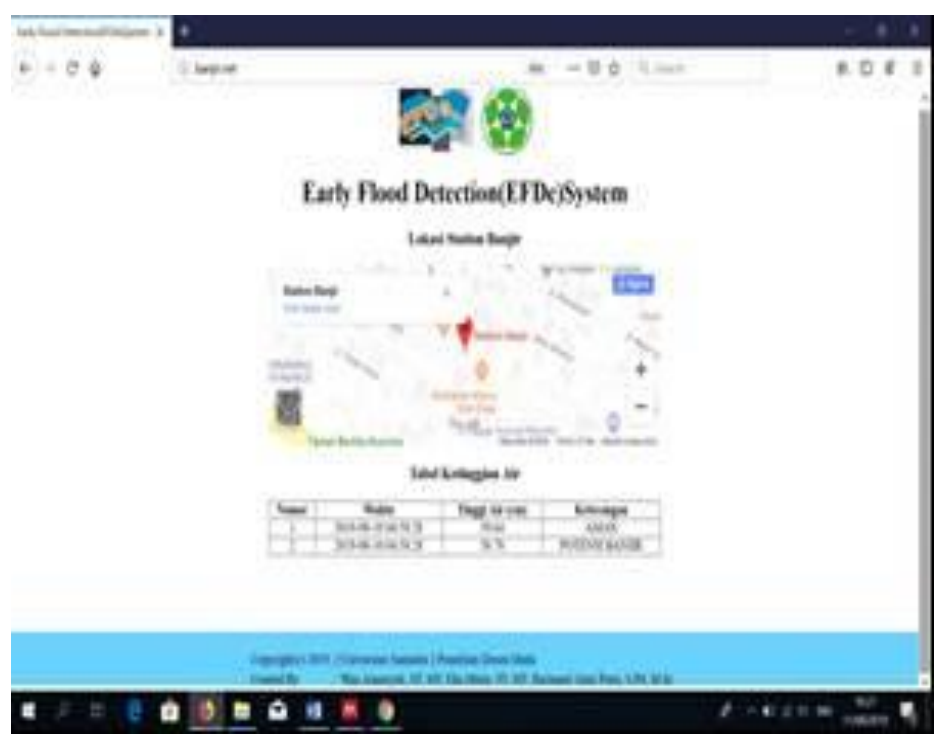

Figure 4. EFDe Page Interface for Desktop Browser

Justification of the water level indicator on the EFDe system is based on table 1.

Table 1. Justification of water level indicators

\begin{tabular}{ccc}
\hline No & Water Level $(\mathbf{C m})$ & Description \\
\hline $\mathbf{1}$ & $<40$ & Safe \\
$\mathbf{2}$ & $>=40$ & Potential Flood \\
\hline
\end{tabular}

From Table 1 . We can see that when the water level read by the sensor is less than 40 $\mathrm{cm}$, the area has no potential for a flood. However, when the water level reaches $>=40$ $\mathrm{cm}$, the area has a flood potential. When the indicator table displays information on POTENTIAL FLOOD, then the EFDe system will give an alarm signal around the location of Flood Station. The alarm response at the Flood Station is 5-10 seconds from the data received by the server, and the duration is as long as the water level meets the FLOOD POTENTIAL signal and will stop beeping after 10-15 seconds after the water level meets the SAFE signal.

- Measurement and Calibration Results
The characterization of the HCSR-04 sensor is carried out by directing the HCSR04 sensor into a container filled with water with the varying water level. The variation in water level in the container is obtained based on the volume of water added in the container. The height of the water surface measured compared by meter and sensor readings are presented in table 2 below:

Table 2. Sensor Accuracy Measurement Results

\begin{tabular}{cc}
\hline \multicolumn{2}{c}{ Results } \\
\hline \multicolumn{2}{c}{ Measurement Test } \\
\hline Ruler $(\mathbf{c m})$ & Sensor $(\mathbf{c m})$ \\
\hline 2 & 0 \\
20 & 19,88 \\
40 & 39,78 \\
60 & 59,9 \\
80 & 79,87 \\
100 & 99,76 \\
\hline
\end{tabular}

The difference in measurement results between the ruler and the sensor in table 2 with a step size of $20 \mathrm{~cm}$ can obtain a comparison curve as shown in Figure 4. 


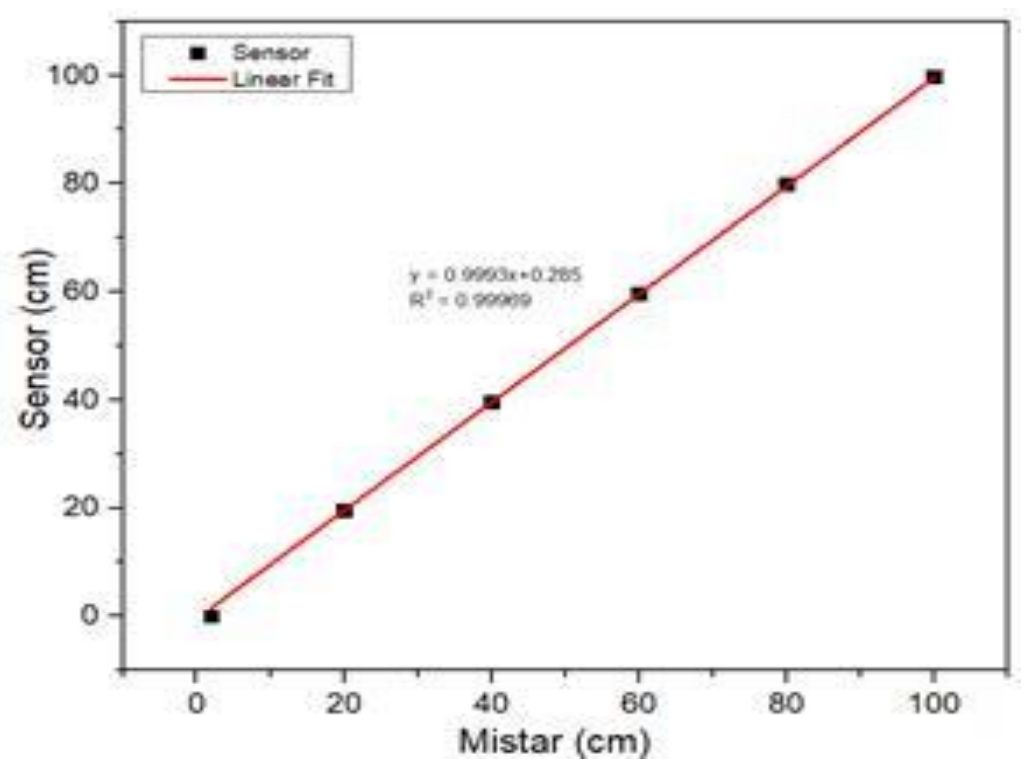

Figure 5. The connection result of ruler vs sensor measurement

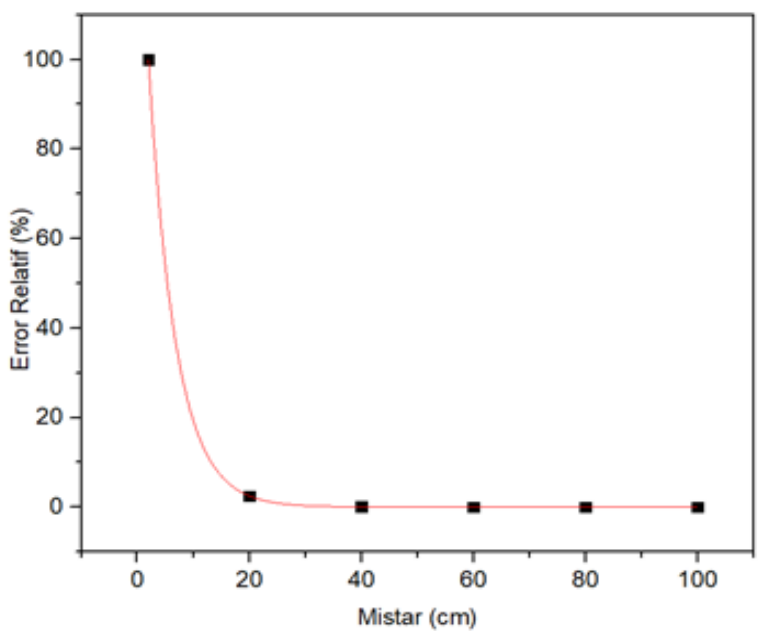

Figure 6. The relative error plot of the measurement data

From Figure 5 we can see a significant correlation value of the distance between the measurement results using the ruler with the measurement results of sensor readings. The coefficient of determination $\mathrm{R} 2=0.9996$ explains the accuracy value generated by the sensor of the ruler measurement is $99.99 \%$. The relative error profile is also shown by each measurement data which is presented in graphical form in Figure 6.

Figure 6 shows the relative error value of the measurement data. The biggest error is at $2 \mathrm{~cm}$ which is $100 \%$. The biggest error value is caused by a minimum sensor size limit of 2 $\mathrm{cm}$. However, the bigger the measurement distance the smaller the relative error value.
The results obtained from this study are Early flood detection System or abbreviated as EFDe is able to function in real-time and provide real-time information quickly and accurately, this can be seen from the sensor response and the measurement accuracy results that have been calibrated and show the relative error values that are so small that can be said that the sensor on EFDe has an accuracy value of $99.99 \%$.

\section{Conclusion}

An Early Flood Detection device called the Early Flood Detection (EFDe) System has been designed using the Internet of Thing system. EFDe system has a speed of sending 
data 10-15 seconds. The accuracy of the EFDe System in reading water levels is 99.99 per cent. The water level carried by the EFDe System can be monitored in realtime through the website or android. So the EFDe system can properly be applied in flood-prone areas.

\section{Acknowledgement}

This research was funded by DIPA Universitas Samudra through LPPM-PM Universitas Samudra through the Research of Young Lecturers with Contract Number: 340/UN54.6/LT/2019.

\section{References}

1. Lewi EB, Sunarya U, Ramadan DN. Sistem Monitoring Ketinggian Air Berbasis Internet Of Things Menggunakan Google Firebase. eProceedings of Applied Science. 2017 Aug 1;3(2):1-8

2. Indrasari W, Iswanto BH, Andayani M. Early Warning System of Flood Disaster Based on Ultrasonic Sensors and
Wireless Technology. InIOP Conference Series: Materials Science and Engineering 2018 Apr (Vol. 335, No. 1, p. 012005). IOP Publishing.

3. Muzakky A, Nurhadi A, Nurdiansyah A, Wicaksana G. Perancangan Sistem Deteksi Banjir Berbasis IoT. In Conference on Innovation and Application of Science and Technology (CIASTECH) 2018 Oct 3 (Vol. 1, No. 1, pp. 660-667).

4. B. K. Durga, A. Ece, S. Peter, and S. E. College. Design of Early Warning Flood Detection Systems. 2018;5(4):794-799

5. Indianto W, Kridalaksana AH, Yulianto Y. Perancangan Sistem Prototipe Pendeteksi Banjir Peringatan Dini Menggunakan Arduino Dan PHP. Informatika Mulawarman: Jurnal Ilmiah Ilmu Komputer. 2017 Feb 12;12(1):45-9.

6. Efendi L, Wildian W. Rancang Bangun Sistem Deteksi dan Informasi Lokasi Banjir Berbasis GSM. Jurnal Fisika Unand. 2018 Oct 1;7(4):328-33. 